\title{
Evaluation of Exposures to Styrene During Ultraviolet Cured-in-place Pipe Installation
}

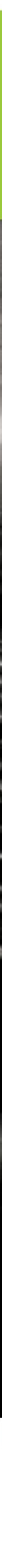

Ryan F. LeBouf, PhD, CIH Dru A. Burns, MS

March 2019

This report replaces the online report dated January 2019.

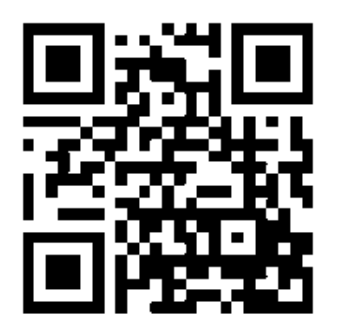

U.S. Department of Health and Human Services Centers for Disease Control and Prevention National Institute for Occupational Safety and Health

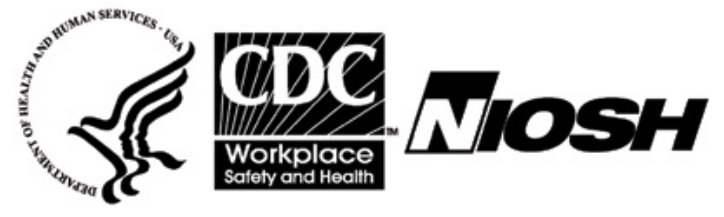




\section{Contents}

Highlights.....................................................

Abbreviations .......................................... iv

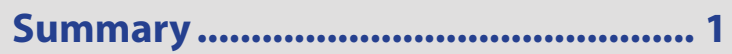

Introduction ....................................... 2

Background............................................... 2

Process Description ................................ 3

Methods ................................................ 3

Results .................................................... 8

Discussion .......................................... 10

Conclusions ...................................... 11

Recommendations............................ 11

References......................................... 15

Appendix A:Tables ............................ 17

Appendix B: Figures ....................... 20

Acknowledgements........................... 28

The employer is required to post a copy of this report for 30 days at or near the workplace(s) of affected employees. The employer must take steps to ensure that the posted report is not altered, defaced, or covered by other material.

This report was revised to clarify the company's practices to control styrene exposures at the time of the survey. The authors also corrected a footnote in Table 3 and in the text to indicate the ventilator blower fan was not used on the first day of air sampling.

The cover photo is a close-up image of sorbent tubes, which are used by the HHE Program to measure airborne exposures. This photo is an artistic representation that may not be related to this Health Hazard Evaluation. 


\section{Highlights of this Evaluation}

The Health Hazard Evaluation Program of the National Institute for Occupational Safety and Health received a management request in October 2017 from an installation company who repaired underground pipes using ultraviolet cured-in-place pipe. The request stated a desire to investigate styrene levels at the worksites to determine whether exposures were controlled using current practices and identify any areas for improvement.

\section{What We Did}

- We conducted an initial visit during February 5-6, 2018; during this visit we measured personal task-based exposures to styrene and divinylbenzene.

- We conducted a second visit during June 6-7, 2018; during this visit we measured personal task-based exposures to styrene and total volatile organic compounds

- During both visits, we measured total volatile organic compounds at the face of the manhole using a photoionization detector and styrene concentrations at the face of the manhole using a Fourier transform infrared spectrometer.

- We collected bulk samples of cured liner for styrene emissions testing.

\section{What We Found}

- One personal exposure to styrene during grinding a cured pipe (140 parts per million [ppm]) exceeded the 15-minute short-term exposure limit of $100 \mathrm{ppm}$ when the manhole ventilator blower fan was not used.

- The next highest exposure to styrene occurred during cutting and taping of the liner (51 ppm) when the manhole ventilator blower fan was not used.

- No personal exposures exceeded the short-term exposure limit to styrene when the manhole ventilator blower fans were used.

- Increases in styrene and total volatile organic compounds area air concentrations were associated with activities occurring in the

We evaluated personal task exposures to and area emissions of styrene and total volatile organic compounds during installation of cured-inplace pipe. Styrene exposures exceeded the NIOSH short-term exposure limit for styrene of 100 ppm once during grinding of a cured pipe when the manhole was not ventilated. Tasks with the highest exposure risks were grinding cured pipe and cutting and taping the liner. Styrene and total volatile organic compound emissions at the manhole face revealed the effectiveness of the ventilators at reducing styrene air concentrations during our sampling. We recommend ventilating the manholes at all times during the tasks where employees might be exposed to uncured or cured liners including cutting and taping liners, installing packers, installing light trains, and grinding cured pipes. 
manhole and showed a reduction in measured styrene when the manhole ventilator blower fans were used.

- Styrene was emitted from cured liner.

\section{What the Employer Can Do}

- Provide employees with training on potential hazards such as styrene exposure.

- Require employees to continue to immediately bag excess liner material and contaminated gloves.

- Require employees to continue to ventilate the manholes at all times during the tasks where employees might be exposed to uncured or cured liners including cutting and taping liners, installing packers, installing light trains, and grinding cured pipes.

- Monitor the ventilator flexible duct for unnecessary bends that can reduce air supply and ensure it only has one $90^{\circ}$ bend at the point of entry into the manhole.

- Require employees to be clean shaven before donning N95 respirators.

- Encourage employees to report health symptoms related to styrene exposures to their healthcare provider and the health and safety officer.

- Conduct additional sampling for styrene if employees report health symptoms or a change occurs to processes, materials, or work practices.

\section{What Employees Can Do}

- Continue to immediately bag excess liner material and contaminated gloves.

- Continue to ventilate the manholes at all times during the tasks where employees can be exposed to uncured or cured liners including cutting and taping liners, installing packers, installing light trains, and grinding cured pipes.

- Ensure the manhole ventilator flexible duct only has one $90^{\circ}$ bend at the point of entry into the manhole.

- Shave daily when using N95 respirators (dust masks).

- Report health symptoms related to styrene exposure to your doctor and the health and safety officer. Health symptoms might include changes in color vision, tiredness, feeling drunk, slowed reaction time, concentration problems, balance problems, hearing loss, or respiratory symptoms (such as cough, shortness of breath, wheezing, or chest tightness). 
This page left intentionally blank 


\section{Abbreviations}

$\mathrm{ACGIH}^{\oplus} \quad$ American Conference of Governmental Industrial Hygienists

APF

Assigned protection factor

CFR

Code of Federal Regulations

CIPP

Cured-in-place pipe

FTIR

Fourier transform infrared spectrometer

IDLH

Immediately dangerous to life or health

IARC

International Agency for Research on Cancer

LOD

Limit of detection

$\mu \mathrm{g}$

Microgram

$\mathrm{mg} /(\mathrm{kg} \cdot \mathrm{h})$

Milligrams per kilogram hour

$\mathrm{mL}$

NAICS

Milliliter

$\mathrm{NIOSH}$

North American Industry Classification System

OEL

National Institute for Occupational Safety and Health

OSHA

Occupational exposure limit

ppm

Occupational Safety and Health Administration

PID

Parts per million

REL

Photoionization detector

$\mathrm{RH}$

Recommended exposure limit

STEL

Relative humidity

TVOC

Short-term exposure limit

$\mathrm{TLV}^{\oplus}$

Total volatile organic compound

TWA

Threshold limit value

UV

Time-weighted average

VOC

Ultraviolet

Volatile organic compound 


\section{Summary}

In October 2017, the Health Hazard Evaluation Program of the National Institute for Occupational Safety and Health (NIOSH) received a request from the management of an ultraviolet cured-in-place pipe installer regarding styrene exposures at the worksites. The request sought to determine whether exposures were controlled using current practices and identify areas for improvement. We conducted an initial visit during February 5-6, 2018, and performed preliminary sampling at one site per day. We conducted a second visit during June 6-7, 2018, and performed additional sampling at one site per day. We monitored one installation each day. Both visits consisted of collecting personal breathing zone air samples for styrene. Both visits also consisted of area sampling for total volatile organic compounds and styrene using real-time monitors. During the second visit, we collected real-time total volatile organic compound exposures by placing monitors on employees. We collected bulk samples of cured pipe for styrene emissions testing.

One personal exposure during grinding a cured pipe was above the NIOSH short-term exposure limit of 100 parts per million when the manhole ventilation blower fan was not being used to provide dilution of air from outside the manhole. No personal exposures were above the NIOSH short-term exposure limit when the manhole ventilator blower fans were used. Area sampling results for total volatile organic compound and styrene emissions at the manhole face increased when cured-in-place pipe installation activities occurred in the manhole and demonstrated a reduction in measured styrene when manhole blower ventilators were used.

Styrene was emitted from the uncured and cured resin. Emissions testing of the cured liner revealed emission factors that could cause styrene air concentrations to be in the parts per million range in manholes for sewers and storm water drains during cured-in-place pipe installation. For example, during grinding of the cured pipe, the surface area available for emissions increased, and the trapped styrene was released, leading to an increase in measured styrene exposures during this task.

Dilution ventilation appeared to be effective at reducing personal exposures to below the NIOSH short-term exposure limit for styrene during the two cured-in-place pipe installation sampling events reported here. We recommend continued use of the manhole ventilation blower fans. We recommend additional sampling if employees report health symptoms associated with styrene exposure, such as excessive tiredness, changes in color vision, slowed reaction time, concentration problems, balance problems, feeling drunk, hearing loss, or respiratory symptoms. We also recommend additional sampling if work site conditions change in a way that could increase employee exposures to styrene such as changes to processes, materials, or work practices. 


\section{Introduction}

In October 2017, the Health Hazard Evaluation Program of the National Institute for Occupational Safety and Health (NIOSH) received a request from the management of an ultraviolet (UV) cured-in-place pipe (CIPP) installer regarding styrene exposures at the worksites to determine whether exposures were controlled using current practices and identify areas for improvement. We conducted sampling during two site visits where we assessed personal task exposures to styrene, measured emissions of styrene and volatile organic compounds (VOCs), and collected bulk samples of cured liner. We conducted preliminary sampling during February 5-6, 2018, during installation of two sewer pipe repairs. In March 2018, we provided results from the preliminary sampling to the company. We conducted additional air sampling during June 6-7, 2018, during installation of two storm drain pipe repairs. In July 2018, we provided sampling results from the industrial hygiene survey to the company.

\section{Background}

\section{CIPP}

CIPP is a trenchless technology used to repair sanitary sewer, stormwater, and drinking water pipes. A flexible uncured resin-impregnated liner is inserted into a damaged pipe and then cured in place with hot water, steam, or ultraviolet light to a hard finish to assume the shape of the host pipe [NASTT 2015]. There are different types of resins used during the CIPP process, such as styrene-based polyester resin, non-styrene resin, vinyl ester resin, and epoxy resins [Goodman 1998]. The cured resin is what ensures a water-tight seal. Once hot water, steam, or UV light has cured the resin, it cools to a stable temperature and the pipe is ready for use. If lateral pipes off the repaired pipe are present, holes are cut in the repaired pipe walls for access to the lateral pipes. CIPP installation crews often work in confined spaces (e.g., manholes). Confined space entry permits are often required based on the operations and scope of work [OSHA 2018a].

\section{Styrene}

Styrene is a colorless liquid and VOC that occurs naturally in small amounts in certain plants and foods; styrene is commercially produced and used in the manufacture of reinforced plastics and synthetic rubbers [ATSDR 2010]. Work-related exposure to styrene occurs primarily by inhalation and skin contact; some health effects associated with styrene exposure are tiredness, changes in color vision, slowed reaction time, concentration problems, balance problems, feeling drunk, or hearing loss [ATSDR 2010; Campo et al. 2014; Estill et al. 2016]. Styrene exposure is also a potential risk factor for non-malignant respiratory disease among workers in industries using styrene [Nett et al. 2017]. Asthma and obliterative bronchiolitis cases have been reported among styrene-exposed workers [Culliman et al. 2013; Moscato et al. 1987]. In March 2018, the International Agency for Research on Cancer (IARC) changed the classification of styrene from possibly carcinogenic to humans to probably carcinogenic to humans based on limited evidence in humans and sufficient evidence in experimental animals for carcinogenicity [IARC Monographs Vol 121 Group]. 


\section{Process Description}

A schematic of the installation process is presented in Figure 1. The process starts when a repair order is received by the company. The company then places an order from the liner manufacturer, who produces the liner at a wet-out facility, where resin (greenish color) is embedded in the fiberglass liner. The liner has an inner film and a thicker outer film (plastic) that is heat-sealed, completely contains the liner, and controls styrene emissions. The liner is folded, placed in a plastic bag, and crated for delivery. At the installation site, the pipe that needs to be repaired might be cleaned with high-pressure water or by some other means. During the site visits, manhole entry was conducted according to permit-required confined space entry safety protocols including tie-offs to a safety harness attached to the bottom man and air monitoring for hazardous atmospheres such as oxygen deficiency in the manhole. The pipe was checked using a camera robot that pulls the first rope through the pipe before laying the liner. One end of the liner was secured by a rope used to pull the liner through the section of pipe in need of repair. Depending on the length of the repair, the liner can be pulled through the pipe by hand or using a third man winch. The liner was sometimes placed on a piece of plastic, called a slip sheet which lays on the bottom of the pipe. The slip sheet was coated with vegetable oil as a lubricant. The liner was pulled through the pipe, and each end was cut and taped by the bottom man, leaving approximately 26 inches of excess liner in place on each end to allow for the rest of the installation steps to be completed. The resin should not contact water as this negatively affects curing. If water contacts the resin, it turns from green to white. A device called a packer was attached to the blower side of the liner using ratchet straps. Air was blown through the liner to inflate it. The 14-foot light train was checked by firing all the UV bulbs before being placed in the liner on the cure side. A packer was installed after the light train was pulled to the opposite end (blower side). The packers do not make an air-tight seal. The setup was checked using a camera and then cured. The light train was hooked to a cable on a truck that pulls the train at a known speed depending on the pipe diameter and liner thickness. An operator monitored the curing in terms of pressure, temperature, and speed. The speed was slow at the beginning and end of the pipe to allow for curing of the ends but can be increased to a maximum proprietary speed at the center of the pipe. The excess cured pipe was cut using an angle grinder. Fast-setting concrete was used to smooth the pipe edges. The inner film was pulled out from the cured liner and the outer liner stays. The install was checked again with a camera and any lateral pipes sealed by the CIPP were cut using self-propelled or manual cutters (attached to ropes). Typical CIPP repairs are 200 feet to 400 feet with the longest at approximately 950 feet.

\section{Current Practices to Control Exposures}

The company reported immediately bagging excess liner and contaminated gloves to help control exposures to styrene. Ventilation of manholes was not part of the company's current practices; however, the company shared with NIOSH they were considering using a blower ventilation fan to help reduce styrene air concentrations in manholes. 


\section{Methods}

The objectives of the investigation were to evaluate styrene exposures and emissions during CIPP installations and to identify tasks associated with higher exposure risks. Styrene was chosen as the target for sampling because it was the primary volatile component of the resin system associated with negative health effects from exposures. We monitored styrene exposures and emissions during CIPP installations during February 5-6, 2018, and again during June 6-7, 2018. Before the site visits, we reviewed safety data sheets and communicated with the company to learn about the installation process, work force, and current best practices for controlling exposures. We held opening and closing meetings with management and employees during both visits.

During the initial visit in February 2018, we observed two CIPP installations in sewer pipes. The crew consisted of a project manager, a foreman, and four laborers including two bottom men and two top men. A bottom man entered the manhole on the cure side and the blower side. A top man assisted by handing them tools and supplies as needed. The cure truck was located adjacent to the cure side and contained the light train and cure monitoring equipment, which was controlled by an operator. The blower truck was located adjacent to the blower side and contained the liner and air supply equipment to inflate the liner. The service truck was located adjacent to the cure side and contained tools needed for the installation such as winches and cutters. The process at each installation site took approximately one day. The first installation occurred on the afternoon of February 5, 2018, during which an 8-inch diameter, 40-foot sewer line was repaired. The manholes were not ventilated. Manhole depth was 5.5 feet on the cure side and 3.5 feet on the blower side. The second installation occurred on the morning of February 6, 2018, during which an 8-inch diameter, 195-foot sewer line was repaired, and the manholes were ventilated with rescue ventilators rated at 722 cubic feet per minute of air with a $90^{\circ}$ bend (Figure 2). The second repair was a connected section of the sewer line from the previous day.

During the second visit in June 2018, we observed two CIPP installations in storm water pipes. The crew consisted of a foreman, seven laborers including two bottom men and two top men. A bottom man entered the manhole on the cure side and the blower side. A top man assisted them by handing tools and supplies as needed. The additional laborers provided support as needed. The cure truck was located adjacent to the cure side and contained the light train and cure monitoring equipment, which was controlled by an operator. The blower truck was located adjacent to the blower side and contained the liner and air supply equipment to inflate the liner. The service truck was located adjacent to the cure side and contained tools needed for the installation such as winches and cutters. The process at each installation site took approximately one day. The first installation occurred on June 6, 2018, during which a 30-inch diameter, 94-foot storm drain line was repaired. The second installation occurred on June 7, 2018, during which a 3-foot diameter, 99-foot storm drain line was repaired. The manhole openings were approximately two feet wide and 13 feet deep with a five feet chamber diameter. The manholes were ventilated during sampling on both days with rescue ventilators rated at 709 cubic feet per minute of air with a $90^{\circ}$ bend. 


\section{Personal Protective Equipment}

During both visits, we observed the use of high visibility gear, shirts with minimum 3-inch sleeves, hard hats, steel-toed shoes, and safety goggles for all onsite employees. We observed bottom men using disposable Tyvek ${ }^{\circledR}$ protective coveralls with hoods, N95 disposable filtering facepiece respirators (during grinding), safety goggles, and disposable medical-grade nitrile gloves during grinding the cured pipe. We noted facial hair on employees that reduced the effectiveness of the N95 disposable respirators. We observed considerable noise levels coming from the compressor blower on the blower truck during inflation of the liner. We did not measure the sound levels. The health and safety officer for the company reported that the operator of the compressor truck uses ear muffs, and employees within 25 feet of the truck use ear plugs.

\section{Styrene Air Sampling and Analysis Using Occupational Safety and Health Administration (OSHA) Method ORG-89}

We collected personal air samples for styrene and divinylbenzene on coconut shell charcoal tubes coated with 4-tert-butylcatechol using Occupational Safety and Health Administration (OSHA) Method ORG-89 [OSHA 1991]. Divinylbenzene was not an expected emission from the process, but we were able to assess divinylbenzene air concentrations using this technique. Samples were collected at 50 milliliters per minute. Pumps were calibrated before and after sampling with the average flow rate used for calculating air concentrations. Samples were desorbed in $1 \mathrm{~mL}$ of toluene for 30 minutes with occasional shaking and analyzed by Maxxam Laboratories in Novi, MI. The limits of detection (LODs) were 0.9 micrograms $(\mu \mathrm{g}$ ) for styrene and $1.0 \mu \mathrm{g}$ for divinylbenzene. The limits of quantitation were $3.0 \mu \mathrm{g}$ for styrene and $7.9 \mu \mathrm{g}$ for divinylbenzene. Samples were not analyzed for divinylbenzene on the second visit (June 2018) as no divinylbenzene was measured above the detection limit on the first visit (February 2018). In February 2018, we collected 15 personal task air samples. In June 2018, we collected 39 personal task air samples. We did not collect full-shift air samples because the majority of the employees' shift was spent outside the manhole, away from sources of styrene emissions.

The sampling strategy for these task-based samples was not designed for comparison to exposure limits, but when the samples were collected for 15 minutes, we directly compared them to applicable occupational exposure limits to determine whether they had been exceeded. We collected short-term samples during assumed higher-level styrene exposure tasks including (1) cutting and taping the uncured liner, (2) installing the light train and packers, and (3) grinding the cured pipe. These tasks require the bottom man to be present in the manhole and the top man to be at the top of the manhole to assist. During preliminary sampling in February 2018, air samples were collected for the entire duration of tasks requiring the bottom man to be in the manhole. In June 2018, sampling for the task "grinding cured pipe" was sometimes divided into three components: pre-grinding, grinding, and postgrinding. The sampling was divided to identify the worst-case, maximum styrene exposures during this task.

\section{Area Air Sampling and Analysis Using Evacuated Canisters}

We collected instantaneous area air samples for VOCs using evacuated canisters. The 
evacuated canister sampling setup consisted of a 450-mL evacuated canister equipped with an instantaneous flow controller designed for a short sampling duration (less than 30 seconds). Instantaneous samples were taken by opening the evacuated canister to grab a sample of air at the face of the manhole to identify fugitive emissions from the liner installation process.

The canister air samples were analyzed using a pre-concentrator/gas chromatograph/mass spectrometer system [NIOSH 2018], with the addition of acetaldehyde, acetonitrile, and styrene to the list of quantified compounds. The LOD was 0.0008 parts per million (ppm) for styrene based on a 1.5-times dilution factor, which is typical for instantaneous samples. However, LODs are dependent on the pressure inside each canister after the samples have been collected, and they can be higher or lower than typical values.

\section{Real-time Air Sampling}

Handheld photoionization detectors (PID; Tiger ${ }^{\circledR}$, Ion Science Ltd, Cambridge, UK) were used to measure concentrations of total volatile organic compounds (TVOCs) in the air at the face of the manholes for both visits. This detector is non-specific, responding to chemicals with ionization potentials below the energy of the lamp (10.6 electron volts). The detection range of the Tiger is $0.001 \mathrm{ppm}$ to $20,000 \mathrm{ppm}$ (isobutylene). A Fourier transform infrared spectrometer (FTIR; DX4040, Gasmet Technologies, Inc., Toronto, Ontario) was also used to measure real-time styrene air concentrations at the face of the manhole for both visits. The detection range of the FTIR for styrene was $0.16 \mathrm{ppm}$ to $200 \mathrm{ppm}$. A background FTIR spectrum was collected daily with zero grade nitrogen. During the second visit, personal PID monitors (CUB, Ion Science Ltd) were used to measure time-resolved peak TVOC exposures on the bottom man and top man. The detection range for the CUB was $0.001 \mathrm{ppm}$ to 5,000 ppm (isobutylene). The PIDs were calibrated daily onsite with zero air and $10 \mathrm{ppm}$ isobutylene for the Tigers and $100 \mathrm{ppm}$ for the CUBs. CUB and Tiger instrument responses were converted to styrene using the manufacturer's response factor (0.45). Temperature and relative humidity (RH) were monitored using Extech Hygro-Thermometer pens (FLIR, Nashua, NH).

\section{Headspace and Emissions Testing of Cured Pipe Liner}

We collected two bulk samples of cured pipe liner from the initial visit, one from each day. We collected one bulk sample from the first day of the second visit. All samples were stored at room temperature in multiple layers of polyethylene bags. Headspace analysis was performed on the two bulk samples from the initial visit. For headspace analysis, we transferred approximately one gram of solid bulk material into a sealed $40-\mathrm{mL}$ amber volatile organic analysis vial and let it rest for 24 hours at room temperature $\left(70^{\circ} \mathrm{F}\right)$ in the laboratory. Then $2 \mathrm{~mL}$ of headspace air was transferred to a $450-\mathrm{mL}$ canister and pressurized to approximately 1.5 times atmospheric pressure. Using the canister analysis system, the concentrations were calculated in ppm of analytes in the headspace as an indicator of emission potential.

VOC emissions testing was performed on one sample from each visit. Bulk \#2 from the first visit was tested twice. The first test was performed 38 days after collection. The second test 
was performed 157 days after collection. Bulk \#3 from the second visit was tested once, 48 days after collection. Approximately one gram of solid bulk material was transferred into a VOC emissions testing system ( $\mu$-CTE ${ }^{\mathrm{TM}}$ Micro-chamber/Thermal Extractor ${ }^{\mathrm{TM}}$, Markes International, Inc., Sacramento, CA) and flowed 54\% relative humidity (RH) air at 40 milliliters per minute with the chamber temperature conditioned to $25^{\circ} \mathrm{C}$. VOC samples were collected on multi-bed thermal desorption tubes (Universal Tubes, Markes International, Inc.) for one minute at increasing time intervals (i.e., five measurements at two minute intervals, six measurements at five minute intervals, five measurements at ten minute intervals, and two measurements at 15 minute intervals) for two hours. Background VOCs were measured for 19 minutes from the chamber air flow before introduction of the sample. Thermal desorption tube samples were analyzed in the Respiratory Health Division's Organics Laboratory (NIOSH, Morgantown, WV) using an Ultra-xr/Unity-xr analysis system (Markes International, Inc.). Emission factors were calculated based on the mass of material tested, the air flow rate, and the testing chamber volume.

\section{Exposure Limits}

We use mandatory (legally enforceable) and recommended occupational exposure limits (OELs) when evaluating workplace hazards. OELs have been developed by federal agencies and safety and health organizations to prevent adverse health effects from workplace exposures.

Occupational Safety and Health Administration (OSHA) [Mandatory]

The U.S. Department of Labor's OSHA ceiling limits are legal limits that are enforceable in workplaces covered under the Occupational Safety and Health Act. OSHA permissible exposure limits represent the legal maximum for a time-weighted average (TWA) exposure to a physical or chemical agent over a work shift [OSHA 2017]. OSHA short-term exposure limits (STELs) are the legal maximum average exposure for a 15-minute time period. Some chemicals also have an OSHA ceiling value that represent levels that must not be exceeded at any time. For styrene, the OSHA STEL is $100 \mathrm{ppm}$, and the OSHA ceiling value is $200 \mathrm{ppm}$ [OSHA 2018b]. OSHA does not have exposure limits for divinylbenzene.

American Conference of Governmental Industrial Hygienists (ACGIH) [Recommended] The American Conference of Governmental Industrial Hygienists (ACGIH) is a professional, not-for-profit scientific association that reviews existing published, peer-reviewed scientific literature and publishes recommendations for levels of substances in air. These recommendations are called threshold limit values (TLVs $\left.{ }^{\circledR}\right)$ [2018a]. ACGIH TLVs are not standards; they are health-based guidelines derived from scientific and toxicological information. ACGIH provides TLV-TWA guidelines that are levels that should not be exceeded during any 8-hour workday of a 40- hour workweek. ACGIH also provides TLVSTEL guidelines that are 15-minute exposure levels that should not be exceeded during a workday. For styrene, the ACGIH TLV is $20 \mathrm{ppm}$, and the ACGIH TLV-STEL is $40 \mathrm{ppm}$ [ACGIH 2018a]. Styrene TLVs are currently under review with a proposed reduction in the exposure limits and modification to the notations (See Notice of Intended Changes) [ACGIH 2018b]. For divinylbenzene, ACGIH TLV is 10 ppm; ACGIH does not have a TLV-STEL for divinylbenzene. 
National Institute for Occupational Safety and Health (NIOSH) [Recommended] NIOSH provides recommended exposure limits (RELs) as TWA concentrations that should not be exceeded over an 8 or 10-hour work shift, during a 40-hour workweek [NIOSH 2010]. RELs are intended to be protective over a 45-year working lifetime. NIOSH also provides STELs that are 15-minute TWAs. For some chemicals, NIOSH has Immediately Dangerous to Life or Health (IDLH) values. An IDLH value is a concentration of an air contaminant that can cause death or immediate or delayed permanent adverse health effects, or prevent escape from such an environment. For styrene, the NIOSH REL is $50 \mathrm{ppm}$, the NIOSH STEL is 100 ppm, and the IDLH is $700 \mathrm{ppm}$. For divinylbenzene, the NIOSH REL is $10 \mathrm{ppm}$. NIOSH does not have a STEL for divinylbenzene.

\section{Statistical Analysis}

We performed analyses using Excel (Microsoft ${ }^{\circledR}$, Redmond, WA), JMP version 12 (SAS Institute Inc., Cary, NC), and SAS version 9.4 (SAS Institute Inc.). When the measured values presented in the report are from samples below the LODs they are denoted by a " $<$ " symbol.

\section{Results}

\section{Styrene Air Sampling and Analysis Using Occupational Safety and Health Administration (OSHA) Method ORG-89}

For February 2018 sampling, pump flow rates decreased by no more than $10.6 \%$ and increased by no more than $7.1 \%$. Changes in pump flow rate did not substantially affect results or interpretation of results as the sampling durations were short. Temperature and $\mathrm{RH}$ ranged from $38^{\circ} \mathrm{F}$ to $56^{\circ} \mathrm{F}$ and $42 \% \mathrm{RH}$ to $54 \% \mathrm{RH}$ on February 5,2018 and $35^{\circ} \mathrm{F}$ to $43^{\circ} \mathrm{F}$ and $76 \%$ RH to $63 \%$ RH on February 6, 2018. Styrene personal task air sampling results for CIPP sewer liner installation in February 2018 are presented in Table 1. Measurable concentrations of styrene when working in the manhole (bottom man) ranged from less than $0.2 \mathrm{ppm}$ to $140 \mathrm{ppm}$. All styrene measurements collected on employees working outside the manhole (top man) were below the detection limit of $0.3 \mathrm{ppm}$. Ventilating the manholes during the second day (February 6, 2018) generally reduced personal exposures to styrene except for grinding the cured pipe on the blower side. Only one task exposure exceeded the NIOSH STEL of $100 \mathrm{ppm}$. This exposure was $140 \mathrm{ppm}$, which is below the OSHA ceiling of $200 \mathrm{ppm}$, and occurred on the first day in the manhole on the cure side during grinding the cured pipe. All divinylbenzene results were less than $0.4 \mathrm{ppm}$, which is below the limit of detection for the analysis.

For June 2018 sampling, pump flow rates changed by more than 5\% for 29 of 39 samples collected, but the resultant change in air volume collected did not substantially affect the reported results or the interpretation of the results as the sampling durations were short. For example, the reported styrene air concentration for the $28.3 \%$ drop in flow rate would be 1.2 ppm versus $1.0 \mathrm{ppm}$ when the average flow rate is used. Temperature and RH ranged from $70^{\circ} \mathrm{F}$ to $74^{\circ} \mathrm{F}$ and $50 \% \mathrm{RH}$ to $57 \% \mathrm{RH}$ on June 6,2018 , and $69^{\circ} \mathrm{F}$ to $79^{\circ} \mathrm{F}$ and $49 \% \mathrm{RH}$ to 
$62 \% \mathrm{RH}$ on June 7,2018 . Styrene personal task air sampling results for CIPP storm water liner installation in June 2018 are presented in Table 1. Bottom man task exposures to styrene ranged from $0.6 \mathrm{ppm}$ to $33.5 \mathrm{ppm}$. The tasks of cutting and taping the liner and grinding the cured pipe had the two highest exposures at $31.3 \mathrm{ppm}$ and $33.5 \mathrm{ppm}$, respectively. The task of pre-grinding the cured pipe on the blower side (June 7, 2018) had a measured styrene concentration of $23.7 \mathrm{ppm}$ that might have been influenced by two minutes of grinding. The task of grinding the cured pipe was higher on the blower side than the cure side. Top man task exposures to styrene were generally lower than bottom man exposures. Top man task exposures ranged from less than $0.1 \mathrm{ppm}$ to $2.7 \mathrm{ppm}$. All measured exposures were less than the NIOSH STEL of 100 ppm.

\section{Air Sampling and Analysis Using Evacuated Canisters}

Area styrene air concentrations at the manhole face are presented in Table 3 for both visits. The manhole was not ventilated on February 5, 2018. Instantaneous styrene air concentrations collected during the task of grinding the cured pipe on the cure side were reduced from $51.2 \mathrm{ppm}$ to $47.3 \mathrm{ppm}$ when the ventilator was used. Styrene air concentrations during the cutting and taping the liner on the cure side was reduced from 5.8 ppm to $4.1 \mathrm{ppm}$ when the ventilator was used. For the second visit, styrene air concentrations at the manhole face ranged from $0.1 \mathrm{ppm}$ to $40.8 \mathrm{ppm}$. The maximum value occurred during the grinding the cured pipe. The minimum value occurred during two tasks: installing the packers and grinding the cured pipe. The minimum occurring during grinding the cured pipe was surprising given the task and the associated bottom man tube measurements at $33.5 \mathrm{ppm}$, but this might have been a result of when the instantaneous sample was collected in relation to when the grinding occurred.

\section{Real-time Air Sampling}

FTIR styrene air concentrations at the manhole face correlated well with activities and processes occurring in the manhole. "Cutting/Taping Liner and Installing Packer" task occurred between 2:51 and 3:09. Figure 3A depicts an example of this relation for the blower side on February 5, 2018, where styrene air concentrations were observed to increase to 4.2 ppm during "Cutting/Taping Liner and Installing Packer" compared with the same task with a ventilator blowing ambient air into the manhole where styrene air concentrations peaked at $1.1 \mathrm{ppm}$ (Figure 3B). FTIR styrene air concentration began to increase during the process of "Curing," during which time employees were not present in the manhole but was depressed when comparing ventilated to non-ventilated curves. Styrene air concentrations were higher for "Grinding Cured Pipe" on the blower side than "Cutting/Taping Liner and Installing Packer" for both days, which is consistent with styrene sorbent tube sampling results (Table 1). Comparing grinding between days, styrene air concentrations only briefly reached a valley of $4.0 \mathrm{ppm}$ between curing and grinding on the first day and were below 2.0 ppm before grinding on the second day. Styrene concentrations rapidly increased to $24.0 \mathrm{ppm}$ during grinding on the first day (Figure $3 \mathrm{~A}$ ) and increased to $21.0 \mathrm{ppm}$ on the second day (Figure $3 \mathrm{~B}$ ), and rapidly decreased to below $2.0 \mathrm{ppm}$ within minutes after grinding on both days.

As with the FTIR styrene measurements, PID TVOC air concentrations at the manhole face 
correlated well with activities and processes occurring in the manhole. Figure 4 depicts an example of this relation for the blower side on June 7, 2018. Multiple TVOC peaks up to 50 ppm styrene adjusted were observed for "Cutting/Taping Liner." Once the end was taped, TVOC air concentrations were much lower (no more than 10 ppm) for "Installing Packer." Employees were not present in the manhole on the blower side during "Feeding Light Train from Cure Side" or "Curing." Both durations for these activities are approximate. All the grinding tasks had multiple transient peak concentrations with the highest measured peak concentration at 177 ppm during "Grinding Cured Pipe."

Bottom man personal sampling of TVOC (styrene adjusted) exposures revealed peak exposures up to $140 \mathrm{ppm}$ (Figure 5). The exposure pattern correlated well with task activity and proximity to cured and uncured liner material.

\section{VOC Emissions Testing of Cured Pipe Liner}

Styrene was emitted from the cured material of bulk \#1 (June 5, 2018) and bulk \#2 (June 6, 2018) during headspace analysis. Bulk \#1 had a headspace styrene concentration of 1,300 ppm per gram. Bulk \#2 had a headspace styrene concentration of 5,100 ppm per gram. Bulk \#3 was not tested.

For VOC emissions testing, background chamber styrene concentrations were not detected or less than $0.07 \%$ of the measured test concentrations at each time point. Maximum emission factors were $500 \mathrm{mg} /(\mathrm{kg} \cdot \mathrm{h})$ and $750 \mathrm{mg} /(\mathrm{kg} \cdot \mathrm{h})$ for Bulk \#2 and $850 \mathrm{mg} /(\mathrm{kg} \cdot \mathrm{h})$ for Bulk \#3. Bulk \#1 was not tested.

\section{Discussion}

CIPP is a pipe repair method for sanitary sewer, storm sewer, and drinking water pipes increasingly used in the United States [Whelton et al. 2017]. The CIPP method involves inserting an uncured resin-impregnated liner into a damaged pipe and curing it in place with hot water, steam, or UV light. During this evaluation, UV was used as the curing method. Styrene air concentration emissions from hot water and steam CIPP curing methods are likely different leading to varied employee exposures.

We measured styrene exposures and emissions during installation of CIPP liners. One personal exposure during grinding the cured pipe was above the NIOSH STEL of $100 \mathrm{ppm}$ when the manhole ventilator blower was not being used to provide dilution air from outside the manhole. No personal exposures were above the NIOSH STEL when the manhole ventilator blowers were used.

Styrene was emitted from the uncured and cured resin. The emissions from cured resin were likely caused by small amounts of unreacted, residual styrene. Levels of styrene detected in headspaces within enclosed, unventilated vials containing cured liner were much higher than those that would be expected to be present in manholes where the liner is installed. Many factors might affect air concentrations of styrene in manholes, including the amount of liner 
material present, manhole dimensions, engineering controls used such as dilution ventilation, and administrative controls such as removing and containing excess cured liner. The levels of styrene detected during emissions testing of cured liner are higher than would be expected under normal installation conditions caused by higher air exchange rates in the laboratory test chambers and larger exposed surface area of the edges. Residual styrene in milligram quantities might be trapped in the cured resin and slowly released from the exposed surface. Emissions testing of the cured liner revealed emission factors that could produce parts per million range air concentrations in the manholes for sewers and storm water drains observed during our investigation. During grinding of the cured pipe, the surface area available for emissions increases, and the trapped styrene was likely released leading to an increase in measured exposures during this task.

Dilution ventilation appeared to be effective at reducing personal exposures to below the NIOSH STEL for styrene during the two CIPP installation sampling events reported here. We recommend continued use of manhole ventilation blowers. We recommend additional sampling if employees report health symptoms associated with styrene exposure, such as upper respiratory tract irritation, central and peripheral nervous system effects, high frequency hearing loss, and deficits in color vision. We also recommend additional sampling if work site conditions change in a way that could increase employee exposures to styrene such as changes to processes, materials, or work practices.

We did not specifically test for exposures to additional chemicals. Evacuated canisters used to collect instantaneous estimates of styrene air emission can also be used to measure other VOCs. Styrene overwhelmed these samples and made them ineffectual at identifying other VOCs. Additional chemicals are present in the resin system as components to thicken the resin or facilitate curing. Chemical breakdown products might also be present in emissions. Some of these additional chemicals have been identified in emissions from UV-cured CIPP installations [Li et al. 2018].

\section{Conclusions}

Installation of CIPP liners measured during this evaluation emitted styrene. We identified work tasks that might pose an occupational exposure risk to emitted styrene. These risks were reduced by operating manhole ventilating blower units during the following tasks: cutting and taping liners, installing packers, installing light trains, and grinding cured pipes. Work processes implemented by the company before our visit were also likely effective at minimizing styrene emissions. These processes included bagging excess liner immediately and changing gloves regularly when they come into contact with liner resin. Recommendations are made to protect respiratory health by reducing employee exposures to as low as reasonably achievable.

\section{Recommendations}

On the basis of our findings, we recommend the actions listed below. We encourage the CIPP 
installer to use a labor-management health and safety committee or working group to discuss our recommendations and develop an action plan. Those involved in the work can best set priorities and assess the feasibility of our recommendations for the specific situation at the CIPP installer. We recommend additional sampling for styrene personal exposures if the installation process or materials change, or you expect the styrene air concentrations have increased for any reason.

Our recommendations are based on an approach known as the hierarchy of controls. This approach groups actions by their likely effectiveness in reducing or removing hazards. In most cases, the preferred approach is to eliminate hazardous materials or processes and install engineering controls to reduce exposure or shield employees. Until such controls are in place, or if they are not effective or feasible, administrative measures and personal protective equipment might be needed.

\section{Engineering Controls}

Engineering controls reduce employees' exposures by removing the hazard from the process or by placing a barrier between the hazard and the employee. Engineering controls protect employees effectively without placing primary responsibility of implementation on the employee.

1. Continue to ventilate the manholes at all times during the tasks where employees might be exposed to uncured or cured liners including cutting and taping liners, installing packers, installing light trains, and grinding cured pipes.

2. Ensure the manhole ventilator flexible duct only has one $90^{\circ}$ bend at the point of entry into the manhole.

\section{Administrative Controls}

The term administrative controls refers to employer-dictated work practices and policies to reduce or prevent hazardous exposures. Their effectiveness depends on employer commitment and employee acceptance. Regular monitoring and reinforcement are necessary to ensure that policies and procedures are followed consistently.

1. Continue to remove and contain excess liner immediately and change gloves regularly when they come into contact with liner resin.

2. Encourage bottom men to take breaks out of the manhole when needed.

3. As needed, conduct noise surveys by the compressor truck to ensure the level of hearing protection used by employees near the compressor blower is appropriate.

4. Ensure employees understand potential hazards (e.g., styrene, confined space, noise) in the workplace and how to protect themselves. OSHA's Hazard Communication Standard, also known as the "Right to Know Law" [29 CFR 1910.1200] requires that employees are informed and trained on potential work hazards and associated safe practices, procedures, and protective measures. 
5. Employees should report new, persistent, or worsening symptoms (such as tiredness, changes in color vision, slowed reaction time, concentration problems, balance problems, feeling drunk, hearing loss, shortness of breath, cough, wheezing, chest tightness) to their personal healthcare providers and to a designated individual at this workplace. Employees with new, persistent, or worsening symptoms should share this report with their healthcare providers.

\section{Personal Protective Equipment}

Personal protective equipment is the least effective means for controlling hazardous exposures. Proper use of personal protective equipment requires a comprehensive program and a high level of employee involvement and commitment. The right personal protective equipment must be chosen for each hazard. Supporting programs such as training, change-out schedules, and medical assessment might be needed. Personal protective equipment should not be the sole method for controlling hazardous exposures. Rather, personal protective equipment should be used until effective engineering and administrative controls are in place.

1. Provide NIOSH-certified respirators fitted with organic vapor cartridges to protect against styrene if employees experience respiratory irritation, or additional sampling shows personal short-term exposures in excess of $100 \mathrm{ppm}$ styrene. An assigned protection factors (APF) is the level of respiratory protection that a respirator is expected to provide when used appropriately. Hood powered air-purifying respirators have an APF of 25 meaning the styrene short-term air concentrations might be up to $2,500 \mathrm{ppm}(100 \mathrm{ppm} \times 25)$, and an employee can be expected to be protected in this environment when wearing the respirator. Advantages of the loose-fitting hood powered air-purifying respirators are employees might have facial hair, they provide air flow over the face which might assist with combating thermal stress, and they do not require fit testing. Annual training and a respiratory protection program are required. The OSHA APFs can be found in Table 1 of OSHA Respiratory Protection Standard at https://www.osha.gov/pls/oshaweb/owadisp.show document?p $\underline{\text { table}}=$ STANDARDS\&p id $=12716$.

If mandatory respiratory protection is used, a written respiratory protection program is required by the OSHA Respiratory Protection Standard (CFR 29 1910.134), or the equivalent state standard in states with Federal OSHA-approved State Occupational Safety and Health plans.

2. Please be aware that N95 disposable filtering facepiece respirators are not protective against styrene. In cases of dual exposure to dust and styrene, NIOSH-certified organic vapor cartridges (for styrene) and particulate cartridges/filters (for the dust) would be warranted. If voluntary N95 disposable filtering facepiece respirators are used for dust exposure ensure potential N95 users receive a copy of Appendix D of the OSHA Respiratory Protection Standard (or equivalent State OSHA Agency document) (https://www.osha.gov/laws-regs/regulations/standardnumber/1910/1910.134AppD). 
Information about Appendix D and voluntary use of respirators can be found on the OSHA website at https://www.osha.gov/video/respiratory protection/voluntaryuse transcript.html.

\section{Smoking Cessation Program}

Prevention of smoking-related lung disease is important and makes the detection of workrelated adverse effects easier. We recommend implementing a smoking cessation program to assist employees to stop smoking. The Centers for Disease Control and Prevention offers tools and resources for setting up a smoking cessation program [CDC 2018]. 


\section{References}

ACGIH (American Conference of Governmental Industrial Hygienists) [2018a]. 2018 TLVs ${ }^{\circledR}$ and BEIs ${ }^{\circledR}$ : threshold limit values for chemical substances and physical agents and biological exposure indices. Cincinnati, $\mathrm{OH}$ : American Conference of Governmental Industrial Hygienists.

ACGIH [2018b]. Styrene: TLV® chemical substances draft documentation, Notice of intended changes. Cincinnati, $\mathrm{OH}$ : American Conference of Governmental Industrial Hygienists.

ATSDR (Agency for Toxic Substances \& Disease Registry) [2010]. Toxicological profile for styrene. U.S. Department of Health and Human Services, Public Health Service, ATSDR [https://www.atsdr.cdc.gov/toxprofiles/tp53.pdf]. Date accessed: March 2019.

Campo P, Venet T, Thomas A, Cour C, Brochard C, Cosnier F [2014]. Neuropharmacological and cochleotoxic effects of styrene. Consequences on noise exposures. Neurotoxicol Teratol 44:113-120.

CDC (Centers for Disease Control and Prevention) [2018]. Smoking \& tobacco use [https://www.cdc.gov/tobacco/stateandcommunity/tobacco control programs/index.htm].

Date accessed: March 2019.

CFR. Code of Federal Regulations. Washington, DC: U.S. Government Printing Office, Office of the Federal Register.

Cullinan P, McGavin CR, Kreiss K, Nicholson AG, Maher TM, Howell T, Banks J, Newman Taylor AJ, Chen CH, Tsai PJ, Shih TS, Burge PS [2013]. Obliterative bronchiolitis in fibreglass workers: a new occupational disease? Occup Environ Med 70(5):357-359.

Estill CF, Rice CH, Morata T, Bhattacharya A [2016]. Noise and neurotoxic chemical exposure relationship to workplace traumatic injuries: A review. J Safety Res 60:35-42.

Goodman SH ed [1998]. Handbook of thermoset plastics. Noyes Publications: 2nd ed. New Jersey: Noyes Publication.

IARC Monographs Vol 121 Group [2018]. Carcinogenicity of quinoline, styrene, and styrene7,8-oxide. Lancet Oncol 19(6):728-729.

Li X, Ra K, Nuruddin M, Sendesi S, Howarter JA, Youngblood JP, Zyaykina N, Jafvert CT, Whelton AJ [2018]. Outdoor manufacture of UV-cured plastic linings for storm water culvert repair: chemical emissions and residual. Environ Pollut doi: https://doi.org/10.1016/j. envpol.2018.10.080. Date accessed: March 2019. 
Moscato G, Biscaldi G, Cottica D, Pugliese F, Candura S, Candura F [1987]. Occupational asthma due to styrene: two case reports. J Occup Med 29(12):957-960.

NASTT (North American Society for Trenchless Technology) [2015]. Cured-in-place pipe (CIPP) good practices guidelines. $1^{\text {st }}$ ed. Ohio: North American Society for Trenchless Technology.

Nett RJ, Cox-Ganser JM, Hubbs AF, Ruder AM, Cummings KJ, Huang YT, Kreiss K [2017]. Non-malignant respiratory disease among workers in industries using styrene-A review of the evidence. Am J Ind Med 60(2):163-180.

NIOSH (National Institute for Occupational Safety and Health) [2016]. NIOSH pocket guide to chemical hazards [http://www.cdc.gov/niosh/npg/]. Date accessed: March 2019.

NIOSH [2018]. Volatile organic compounds, C1 to C10, Canister method: Method 3900. In Ashley K, O’Connor PF, eds. NIOSH manual of analytical methods (NMAM ${ }^{\circledR}$ ). $5^{\text {th }}$ ed. [https://www.cdc.gov/niosh/nmam/default.html]. Date accessed: March 2019.

OSHA (Occupational Safety and Health Administration) [1991]. OSHA sampling and analytical method: Styrene and divinylbenzene, ORG-89. U.S. Department of Labor, Occupational Safety and Health Administration. [http://www.osha.gov/dts/sltc/methods/ index.html]. Date accessed: March 2019.

OSHA [2018a]. Confined spaces overview [https://www.osha.gov/SLTC/confinedspaces/ index.html]. Date accessed: March 2019.

OSHA [2018b]. exposure limits - Annotated OSHA Z-2 Table [https://www.osha.gov/dsg/ annotated-pels/tablez-2.html]. Date accessed: March 2019.

Whelton AJ, Shannahan J, Boor BE, Howarter JA, Youngblood JP, Jafvert CT [2017]. Curedin-Place-Pipe (CIPP): Inhalation and dermal exposure risks associated with sanitary sewer, storm sewer, and drinking water pipe repairs. NIOSH Science Blog [https://blogs.cdc.gov/ niosh-science-blog/2017/09/26/cipp/]. Date accessed: March 2019. 


\section{Appendix A: Tables}

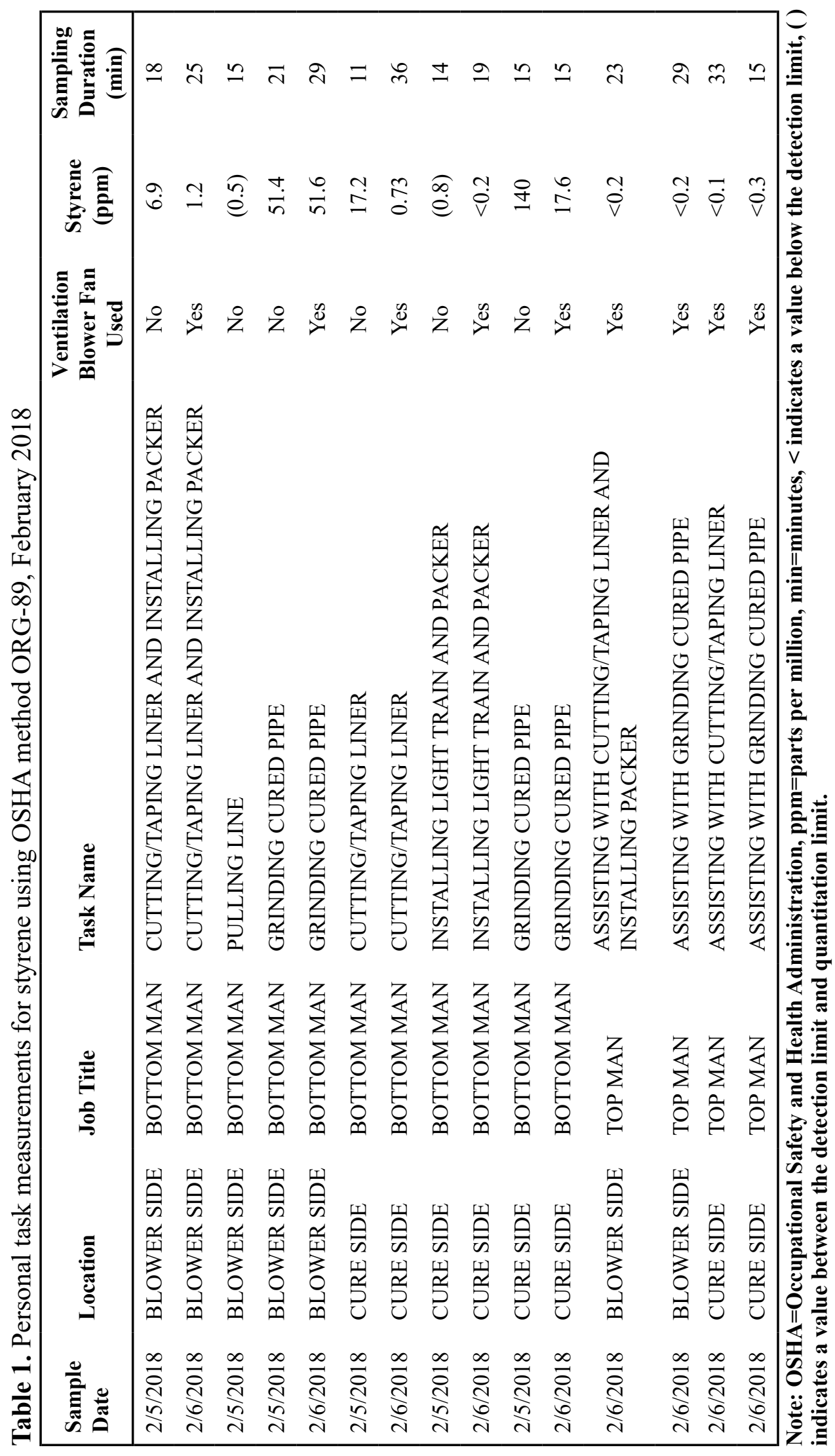


Table 2. Personal task measurements for styrene using OSHA method ORG-89 with manhole ventilated, June 2018

\begin{tabular}{|c|c|c|c|c|c|}
\hline Date & Location & Job Title & Task Name & $\begin{array}{c}\text { Styrene } \\
\text { (ppm) }\end{array}$ & $\begin{array}{c}\text { Sampling } \\
\text { Duration } \\
\text { (min) }\end{array}$ \\
\hline $6 / 6 / 2018$ & BLOWER SIDE & BOTTOM MAN & CUTTING AND TAPING LINER & 31.3 & 30 \\
\hline $6 / 6 / 2018$ & BLOWER SIDE & BOTTOM MAN & GRINDING CURED PIPE & 33.5 & 68 \\
\hline $6 / 6 / 2018$ & BLOWER SIDE & BOTTOM MAN & INSTALLING PACKER & 3.8 & 55 \\
\hline $6 / 6 / 2018$ & BLOWER SIDE & BOTTOM MAN & $\begin{array}{l}\text { LEAK CHECKING PACKER BEFORE } \\
\text { CURING }\end{array}$ & 3.2 & 22 \\
\hline $6 / 6 / 2018$ & BLOWER SIDE & BOTTOM MAN & TAPPING CURED PIPE & $(1.9)$ & 4 \\
\hline $6 / 6 / 2018$ & BLOWER SIDE & TOP MAN & $\begin{array}{l}\text { ASSISTING WITH CUTTING AND } \\
\text { TAPING LINER }\end{array}$ & $(0.3)$ & 32 \\
\hline $6 / 6 / 2018$ & BLOWER SIDE & TOP MAN & $\begin{array}{l}\text { ASSISTING WITH GRINDING } \\
\text { CURED PIPE }\end{array}$ & 1.7 & 67 \\
\hline $6 / 6 / 2018$ & BLOWER SIDE & TOP MAN & $\begin{array}{l}\text { ASSISTING WITH INSTALLING } \\
\text { PACKER }\end{array}$ & $(0.2)$ & 40 \\
\hline $6 / 6 / 2018$ & BLOWER SIDE & TOP MAN & $\begin{array}{l}\text { ASSISTING WITH LEAK CHECKING } \\
\text { PACKER BEFORE CURING }\end{array}$ & $<0.2$ & 24 \\
\hline $6 / 6 / 2018$ & CURE SIDE & BOTTOM MAN & POST-GRINDING CURED PIPE & $(0.6)$ & 14 \\
\hline $6 / 6 / 2018$ & CURE SIDE & BOTTOM MAN & CUTTING AND TAPING LINER & 27.1 & 30 \\
\hline $6 / 6 / 2018$ & CURE SIDE & BOTTOM MAN & GRINDING CURED PIPE & 7.9 & 20 \\
\hline $6 / 6 / 2018$ & CURE SIDE & BOTTOM MAN & $\begin{array}{l}\text { INSTALLING LIGHT TRAIN AND } \\
\text { PACKER }\end{array}$ & 3.3 & 64 \\
\hline $6 / 6 / 2018$ & CURE SIDE & BOTTOM MAN & PRE-GRINDING CURED PIPE & 7.7 & 29 \\
\hline $6 / 6 / 2018$ & CURE SIDE & TOP MAN & $\begin{array}{l}\text { ASSISTING WITH CUTTING AND } \\
\text { TAPING LINER }\end{array}$ & $<0.1$ & 30 \\
\hline $6 / 6 / 2018$ & CURE SIDE & TOP MAN & $\begin{array}{l}\text { ASSISTING WITH INSTALLING } \\
\text { LIGHT TRAIN AND PACKER }\end{array}$ & $<0.1$ & 55 \\
\hline $6 / 6 / 2018$ & CURE SIDE & TOP MAN & $\begin{array}{l}\text { ASSISTING WITH GRINDING } \\
\text { CURED PIPE }\end{array}$ & 0.2 & 64 \\
\hline $6 / 7 / 2018$ & BLOWER SIDE & BOTTOM MAN & CUTTING AND TAPING LINER & 10.6 & 34 \\
\hline
\end{tabular}


Table 2 (cont). Personal task measurements for styrene using OSHA method ORG-89 with manhole ventilated, June 2018

\begin{tabular}{|c|c|c|c|c|c|}
\hline Date & Location & Job Title & Task Name & $\begin{array}{c}\text { Styrene } \\
(\mathrm{ppm})\end{array}$ & $\begin{array}{c}\text { Sampling } \\
\text { Duration } \\
\text { (min) }\end{array}$ \\
\hline 6/7/2018 & BLOWER SIDE & BOTTOM MAN & GRINDING CURED PIPE & 29.2 & 25 \\
\hline $6 / 7 / 2018$ & BLOWER SIDE & BOTTOM MAN & INSTALLING PACKER & 1.3 & 77 \\
\hline $6 / 7 / 2018$ & BLOWER SIDE & BOTTOM MAN & POST-GRINDING CURED PIPE & 8.5 & 27 \\
\hline $6 / 7 / 2018$ & BLOWER SIDE & BOTTOM MAN & PRE-GRINDING CURED PIPE & 23.7 & 22 \\
\hline $6 / 7 / 2018$ & BLOWER SIDE & BOTTOM MAN & TAPPING CURED PIPE & 5.6 & 6 \\
\hline $6 / 7 / 2018$ & BLOWER SIDE & TOP MAN & $\begin{array}{l}\text { ASSISTING WITH CUTTING AND } \\
\text { TAPING LINER }\end{array}$ & 1.0 & 34 \\
\hline $6 / 7 / 2018$ & BLOWER SIDE & TOP MAN & $\begin{array}{l}\text { ASSISTING WITH GRINDING } \\
\text { CURED PIPE }\end{array}$ & 2.7 & 68 \\
\hline 6/7/2018 & BLOWER SIDE & TOP MAN & $\begin{array}{l}\text { ASSISTING WITH INSTALLING } \\
\text { PACKER }\end{array}$ & $(0.1)$ & 76 \\
\hline $6 / 7 / 2018$ & BLOWER SIDE & TOP MAN & $\begin{array}{l}\text { ASSISTING WITH TAPPING CURED } \\
\text { PIPE }\end{array}$ & $(1.0)$ & 5 \\
\hline $6 / 7 / 2018$ & CURE SIDE & BOTTOM MAN & CUTTING AND TAPING LINER & 31.0 & 61 \\
\hline $6 / 7 / 2018$ & CURE SIDE & BOTTOM MAN & GRINDING CURED PIPE & 18.5 & 33 \\
\hline 6/7/2018 & CURE SIDE & BOTTOM MAN & INSTALLING PACKER & 1.5 & 73 \\
\hline $6 / 7 / 2018$ & CURE SIDE & BOTTOM MAN & INSTALLING PACKER & 5.0 & 31 \\
\hline $6 / 7 / 2018$ & CURE SIDE & BOTTOM MAN & PRE-GRINDING CURED PIPE & 5.1 & 31 \\
\hline $6 / 7 / 2018$ & CURE SIDE & BOTTOM MAN & INSTALLING PACKER & 2.9 & 27 \\
\hline 6/7/2018 & CURE SIDE & BOTTOM MAN & INSTALLING PACKER & 0.9 & 47 \\
\hline $6 / 7 / 2018$ & CURE SIDE & BOTTOM MAN & POST-GRINDING CURED PIPE & 4.8 & 15 \\
\hline $6 / 7 / 2018$ & CURE SIDE & TOP MAN & $\begin{array}{l}\text { ASSISTING WITH CUTTING AND } \\
\text { TAPING LINER }\end{array}$ & 1.1 & 62 \\
\hline
\end{tabular}


Table 2 (cont). Personal task measurements for styrene using OSHA method ORG-89 with manhole ventilated, June 2018

\begin{tabular}{|llllcc|}
\hline Date & Location & Job Title & Task Name & $\begin{array}{c}\text { Styrene } \\
\text { (ppm) }\end{array}$ & $\begin{array}{c}\text { Sampling } \\
\text { Duration } \\
\text { (min) }\end{array}$ \\
\hline $6 / 7 / 2018$ & CURE SIDE & TOP MAN & $\begin{array}{l}\text { ASSISTING WITH INSTALLING } \\
\text { PACKER }\end{array}$ & $(0.1)$ & 107 \\
$6 / 7 / 2018$ & CURE SIDE & TOP MAN & $\begin{array}{l}\text { ASSISTING WITH PRE-GRINDING } \\
\text { CURED PIPE }\end{array}$ & $(0.2)$ & 63 \\
$6 / 7 / 2018$ & CURE SIDE & TOP MAN & ASSISTING WITH TAPING LINER & $(0.3)$ & 16 \\
\hline
\end{tabular}

Note: OSHA=Occupational Safety and Health Administration, $\mathbf{p p m}=$ parts per million, $\min =$ minutes, $<$ indicates a value below the detection limit, ( ) indicates a value between the detection limit and quantitation limit. 
Table 3. Area styrene air concentrations at manhole face using instantaneous evacuated canisters, February and June 2018

\begin{tabular}{|lllc|}
\hline Date & Location & Task Name & $\begin{array}{c}\text { Styrene } \\
\text { (ppm) }\end{array}$ \\
\hline 2/5/2018* & BLOWER SIDE & CUTTING AND TAPING LINER AND INSTALLING PACKER & 6.9 \\
2/5/2018* & CURE SIDE & CUTTING AND TAPING LINER & 5.8 \\
2/5/2018* & CURE SIDE & INSTALLING LIGHT TRAIN AND PACKER & 0.4 \\
$2 / 5 / 2018^{*}$ & CURE SIDE & GRINDING CURED PIPE & 51.2 \\
$2 / 6 / 2018$ & CURE SIDE & CUTTING AND TAPING LINER & 4.1 \\
$2 / 6 / 2018$ & CURE SIDE & INSTALLING LIGHT TRAIN AND PACKER & 0.1 \\
$2 / 6 / 2018$ & CURE SIDE & GRINDING CURED PIPE & 47.3 \\
$2 / 6 / 2018$ & BLOWER SIDE & BEFORE GRINDING CURED PIPE & 2.4 \\
$2 / 6 / 2018$ & BLOWER SIDE & GRINDING CURED PIPE & 31.7 \\
$6 / 6 / 2018$ & CURE SIDE & CUTTING AND TAPING LINER & 1.8 \\
$6 / 6 / 2018$ & CURE SIDE & INSTALLING LIGHT TRAIN AND PACKER & 4.9 \\
$6 / 6 / 2018$ & CURE SIDE & GRINDING CURED PIPE & 1.0 \\
$6 / 6 / 2018$ & BLOWER SIDE & CUTTING AND TAPING LINER & 16.6 \\
$6 / 6 / 2018$ & BLOWER SIDE & INSTALLING PACKER & 0.1 \\
$6 / 6 / 2018$ & BLOWER SIDE & LEAK CHECKING PACKER BEFORE CURING & 7.8 \\
$6 / 6 / 2018$ & BLOWER SIDE & GRINDING CURED PIPE & 0.1 \\
$6 / 7 / 2018$ & CURE SIDE & GRINDING CURED PIPE & 20.8 \\
$6 / 7 / 2018$ & BLOWER SIDE & CUTTING AND TAPING LINER & 5.1 \\
$6 / 7 / 2018$ & BLOWER SIDE & INSTALLING PACKER & 0.9 \\
$6 / 7 / 2018$ & BLOWER SIDE & GRINDING CURED PIPE & 40.8 \\
$6 / 7 / 2018$ & BLOWER SIDE & POST-GRINDING CURED PIPE & 7.5 \\
\hline
\end{tabular}

Note: $\mathbf{p p m}=$ parts per million.

*Ventilation blower fan was not used on 2/5/2018. 


\section{Appendix B: Figures}

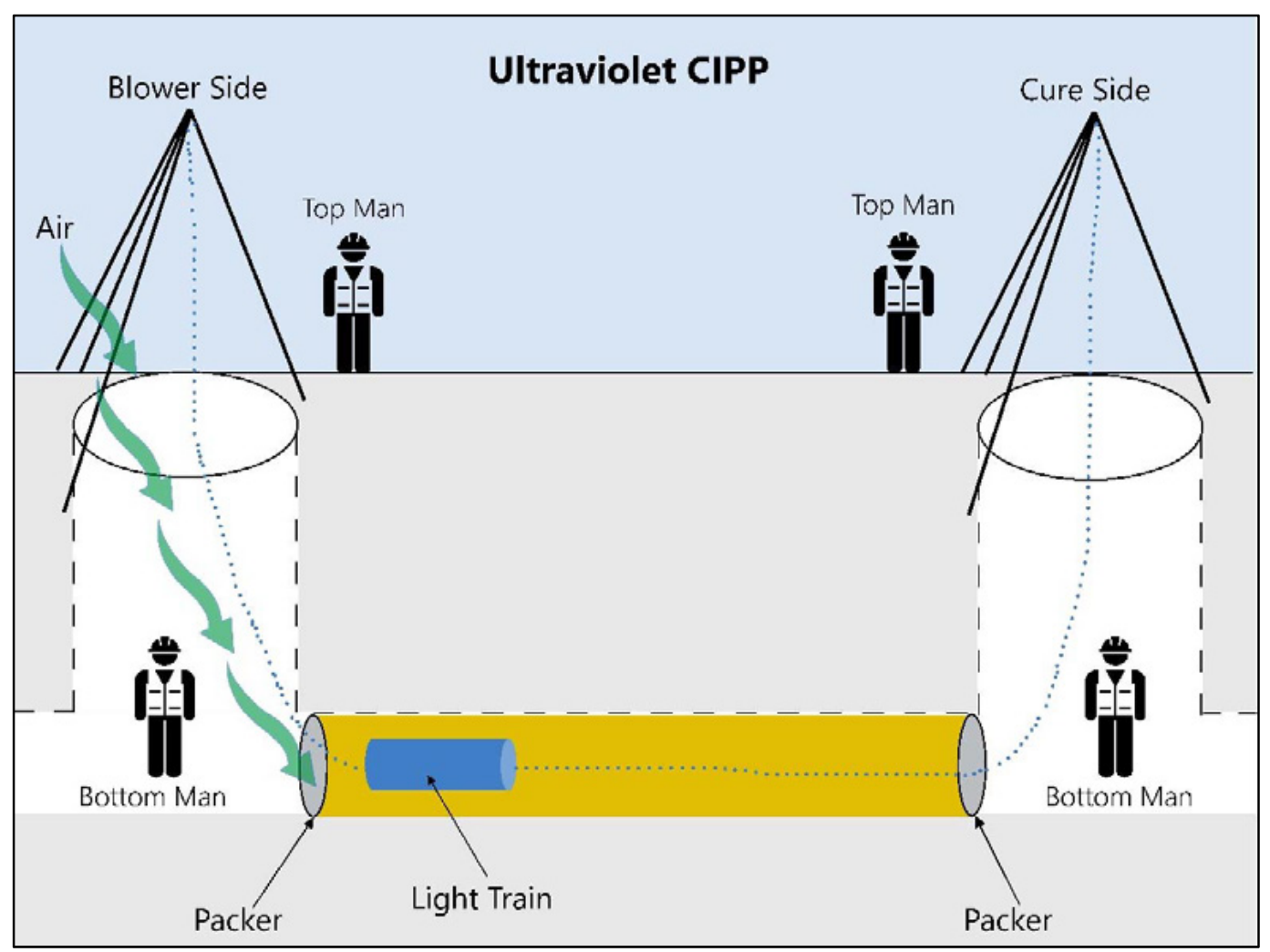

Figure 1. Schematic of ultraviolet cured-in-place pipe installation. Note: Bottom men wear safety harnesses attached to a personnel winch on the tripod above the manhole. Bottom men are not in the manhole during curing. 


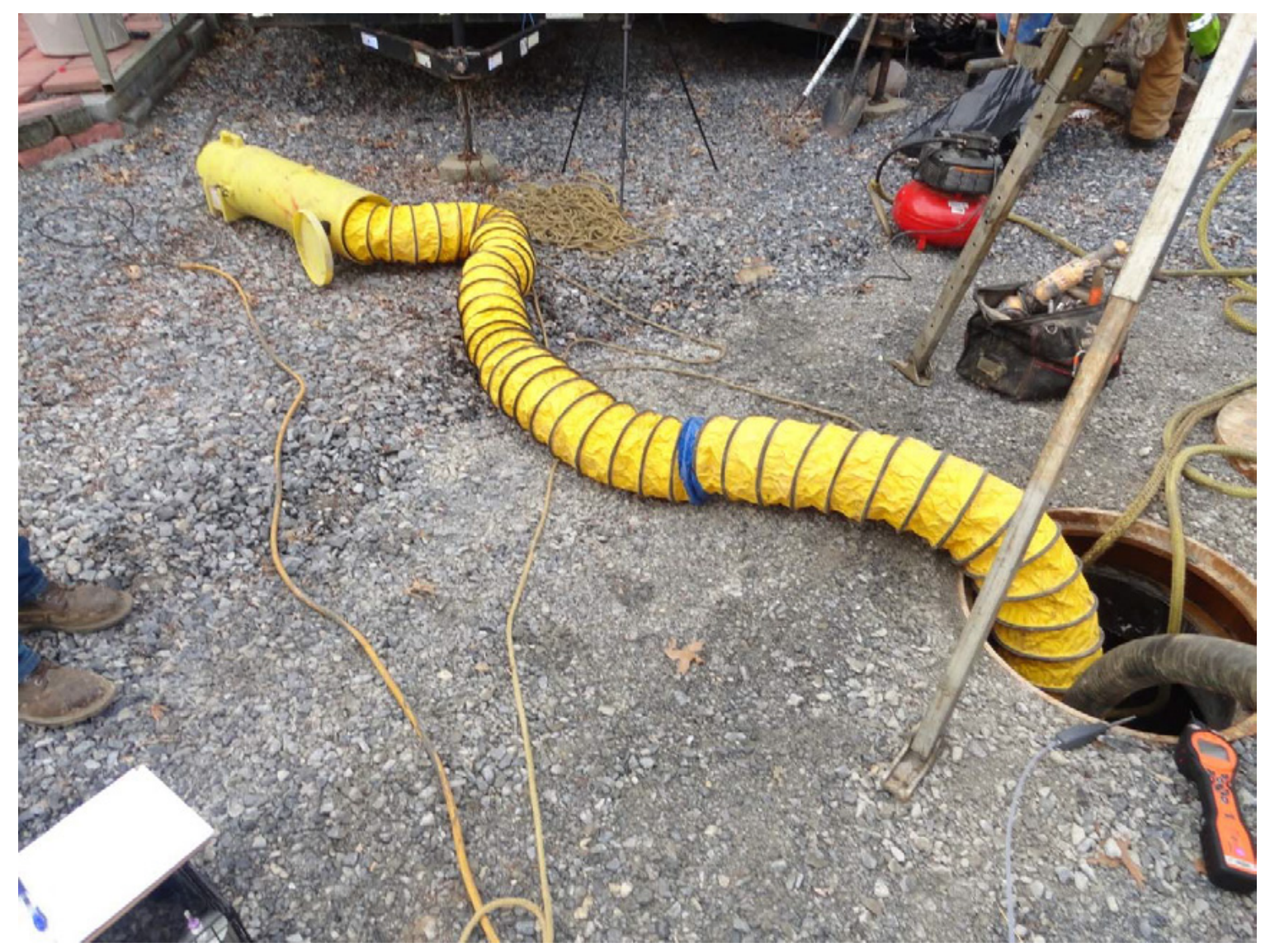

Figure 2. Manhole ventilation blower used to provide dilution ventilation to manhole during CIPP installation tasks, February 6, 2018. 

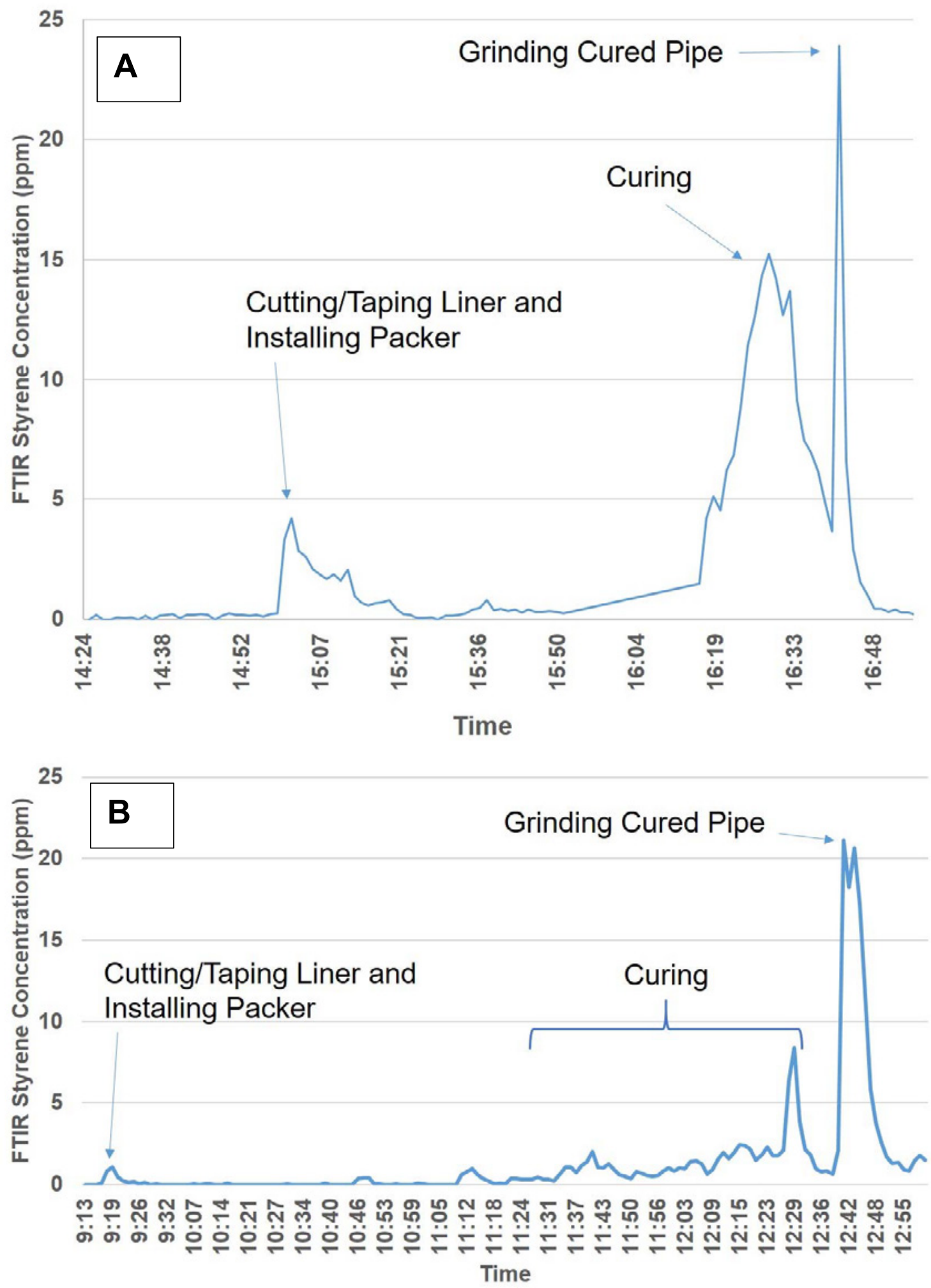

Figure 3. FTIR styrene air concentrations at the manhole face on the blower side (A) without ventilator running on February 5, 2018 and (B) with ventilator running on February 6, 2018. 


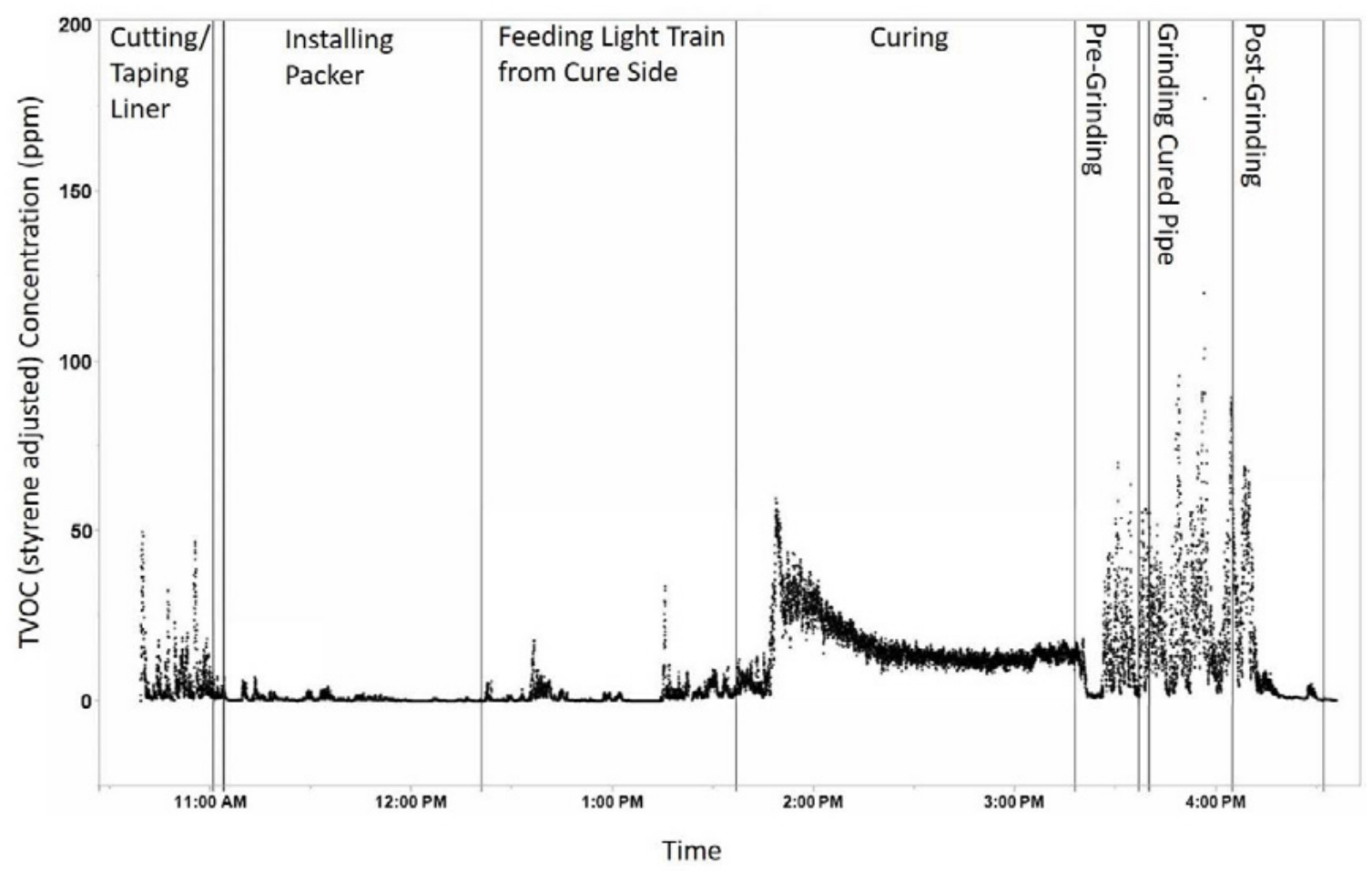

Figure 4. Total volatile organic compound (TVOC; styrene adjusted) air concentrations at the manhole face on the blower side with ventilator running, June 7, 2018.

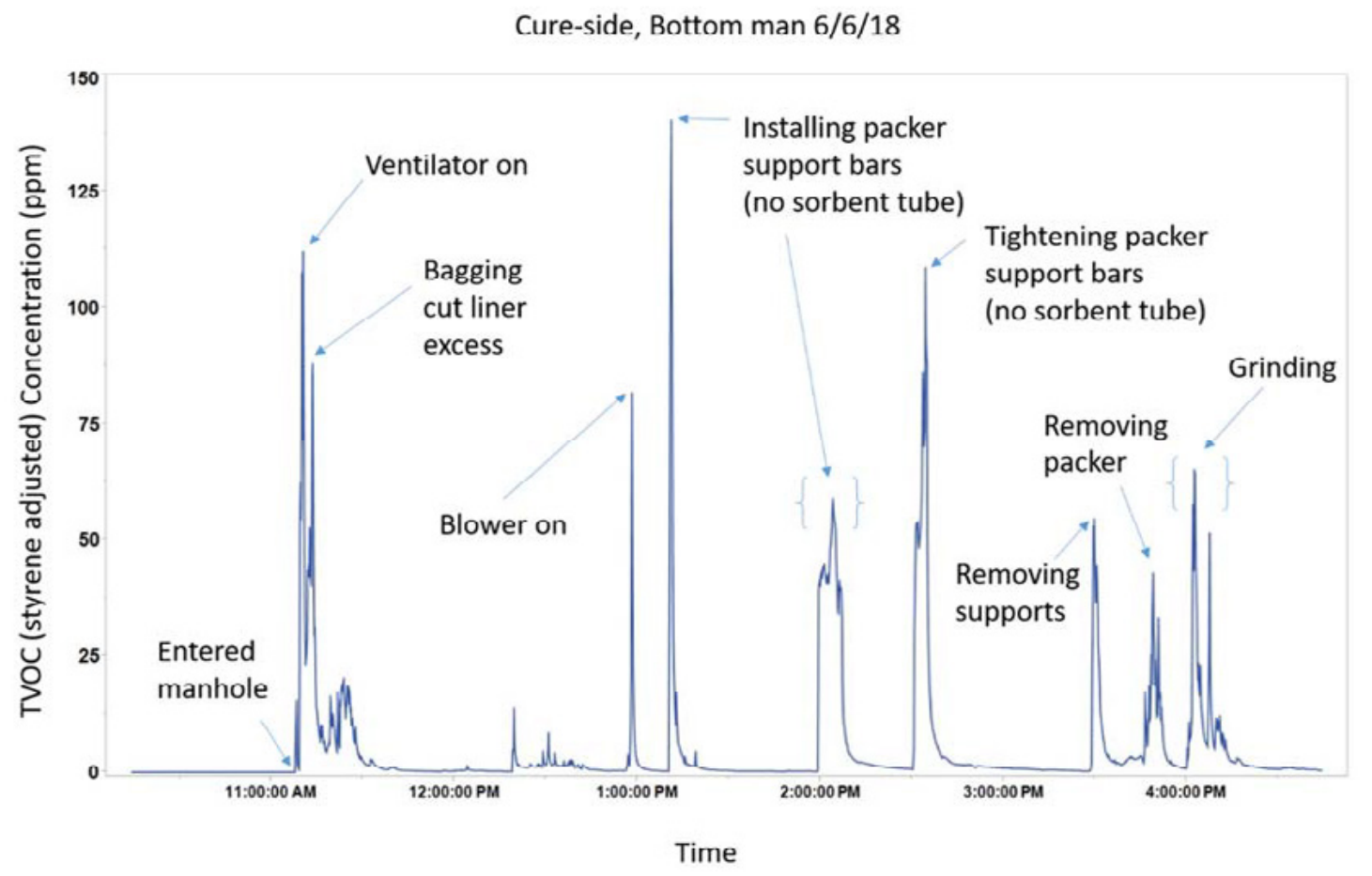

Figure 5. Bottom man personal exposures to total volatile organic compounds (TVOC; styrene adjusted) during installation of 30-inch, 94-foot section of storm water pipe liner on June 6, 2018. 
This page left intentionally blank 
Keywords: NAICS 237110 (Water and Sewer Line and Related Structures), Virginia, curedin-place pipe (CIPP), styrene, volatile organic compounds (VOCs), trenchless technology, confined space 
The Health Hazard Evaluation Program investigates possible health hazards in the workplace under the authority of the Occupational Safety and Health Act of 1970 (29 U.S.C. § 669(a) (6)). The Health Hazard Evaluation Program also provides, upon request, technical assistance to federal, state, and local agencies to investigate occupational health hazards and to prevent occupational disease or injury. Regulations guiding the Program can be found in Title 42, Code of Federal Regulations, Part 85; Requests for Health Hazard Evaluations (42 CFR Part 85).

\section{Disclaimer}

The recommendations in this report are made on the basis of the findings at the workplace evaluated and might not be applicable to other workplaces.

Mention of any company or product in this report does not constitute endorsement by the National Institute for Occupational Safety and Health (NIOSH).

Citations to Web sites external to NIOSH do not constitute NIOSH endorsement of the sponsoring organizations or their programs or products. NIOSH is not responsible for the content of these Web sites. All Web addresses referenced in this document were accessible as of the publication date.

\section{Acknowledgments}

Desktop Publisher: Tia McClelland

Laboratory Support: Michael Aldridge and Anand Ranpara

\section{Availability of Report}

Copies of this report have been sent to the employer and employees at the facility. The state and local health department and the Occupational Safety and Health Administration Regional Office have also received a copy. This report is not copyrighted and may be freely reproduced.

This report is available at http://www.cdc.gov/niosh/hhe/reports/pdfs/2018-0009-3334.pdf.

All other HHE Reports can be found at http://www2a.cdc.gov/hhe/search.asp.

\section{Recommended citation for this report:}

NIOSH [2019]. Health hazard evaluation report: evaluation of exposures to styrene during ultraviolet cured-in-place-pipe installation. By LeBouf RF, Burns DA. Morgantown, WV: U.S. Department of Health and Human Services, Centers for Disease Control and Prevention, National Institute for Occupational Safety and Health, NIOSH HHE Report No. 2018-00093334. 
Delivering on the Nation's promise:

Safety and health at work for all people through research and prevention

To receive documents or other information about occupational safety and health topics, contact NIOSH

Telephone: 1-800-CDC-INFO (1-800-232-4636)

TTY: 1-888-232-6348

email: cdcinfo@cdc.gov

or visit the NIOSH website at http://www.cdc.gov/niosh

SAFER • HEALTHIER • PEOPLE ${ }^{\text {TM }}$ 